\title{
New Business Model For Creative Agency Through Influencer Marketing
}

\author{
Rezi Muhamad Taufik Permana ${ }^{1}$, M. Malik Akbar Rohandi², Yudha Dwi Nugraha ${ }^{3}$ \\ 1, 2, ${ }^{3}$ Universitas Islam Bandung, West Java, Indonesia \\ Email: ${ }^{1}$ rezi.muhamad@gmail.com, moch.malik@unisba.ac.id ${ }^{2}$ \\ yudhadnoegraha@gmail.com ${ }^{3}$
}

\begin{abstract}
Influencer Marketing is seen as one of the best strategies to bring in potential customers when using social media marketing by leveraging the masses of Influencers. The purpose of this study is to analyze the phenomenon of influencer marketing, business models and decision making in the use of influencers in marketing activities for creative agency business people. In this study, we will analyze the social relationships of individuals or groups because influencer marketing can be an appropriate reference group. This study uses secondary data contained in books, white papers, journals, articles which is the basis for a literature review, while primary data uses direct surveys with 200 respondent to social media active users. From the results of this study, it can be concluded that influencers have a significant role in the business processes of creative agencies. Where influencers who have quite significant followers and the variety of content they create make it attractive to consumers.
\end{abstract}

Keywords : Influencer Marketing, Electronic Word of Mouth, Social Media Marketing.

\begin{abstract}
ABSTRAK
Pemasaran Influencer dipandang sebagai salah satu strategi terbaik untuk mendatangkan pelanggan potensial saat menggunakan pemasaran media sosial dengan memanfaatkan massa Influencer. Tujuan dari penelitian ini adalah untuk menganalisis fenomena influencer marketing, model bisnis dan pengambilan keputusan dalam penggunaan influencer dalam kegiatan pemasaran bagi para pelaku bisnis creative agency. Dalam penelitian ini, kami akan menganalisis hubungan sosial individu atau kelompok karena influencer marketing dapat menjadi kelompok referensi yang tepat. Penelitian ini menggunakan data sekunder yang terdapat dalam buku, white paper, jurnal, artikel yang menjadi dasar dari literature review, sedangkan data primer menggunakan survey langsung dengan 200 responden pengguna aktif media sosial. Dari hasil penelitian ini dapat disimpulkan bahwa influencer memiliki peran yang signifikan dalam proses bisnis agensi kreatif. Dimana influencer yang memiliki followers cukup signifikan dan variasi konten yang mereka buat membuatnya menarik bagi konsumen.
\end{abstract}

Kata kunci : Influencer Marketing, Electronic Word of Mouth, Social Media Marketing.

\section{Introduction}

Influencer marketing is a very interesting phenomenon because it is a great balancer and shifts the balance from power to any part of the subject that has the ability to share something (Vodák et al., 2019). Influencers or social media celebrities refer to individuals who become famous through their social media presence, in contrast to traditional celebrities who are famous from films, music, and TV shows (Khamis et al., 2016). To become an Influencer, one of the requirements is to have the power to influence the perception of others in some way. This is because it will be able to help companies to sell a product. Contestabile's (2015) research states 
that many companies have implemented Influencer marketing into their marketing strategies, and the results show that $41 \%$ still spend less than $5 \%$ of their budget on Influencer marketing. Traditional advertising and marketing on TV, print and desktop advertising is becoming less effective. In addition, according to Todisco (2017) between 2015 and 2020 "Influencer marketing" as a search term on Google Trends increased by $400 \%$. This can be interpreted as companies wanting social media influencers after realizing the power of building relationships with each other. Based on the results of a Google Trends search for the last 5 years, it can be seen that the keyword Influencer marketing and Influencer continues to increase as shown in the figure 1 below:

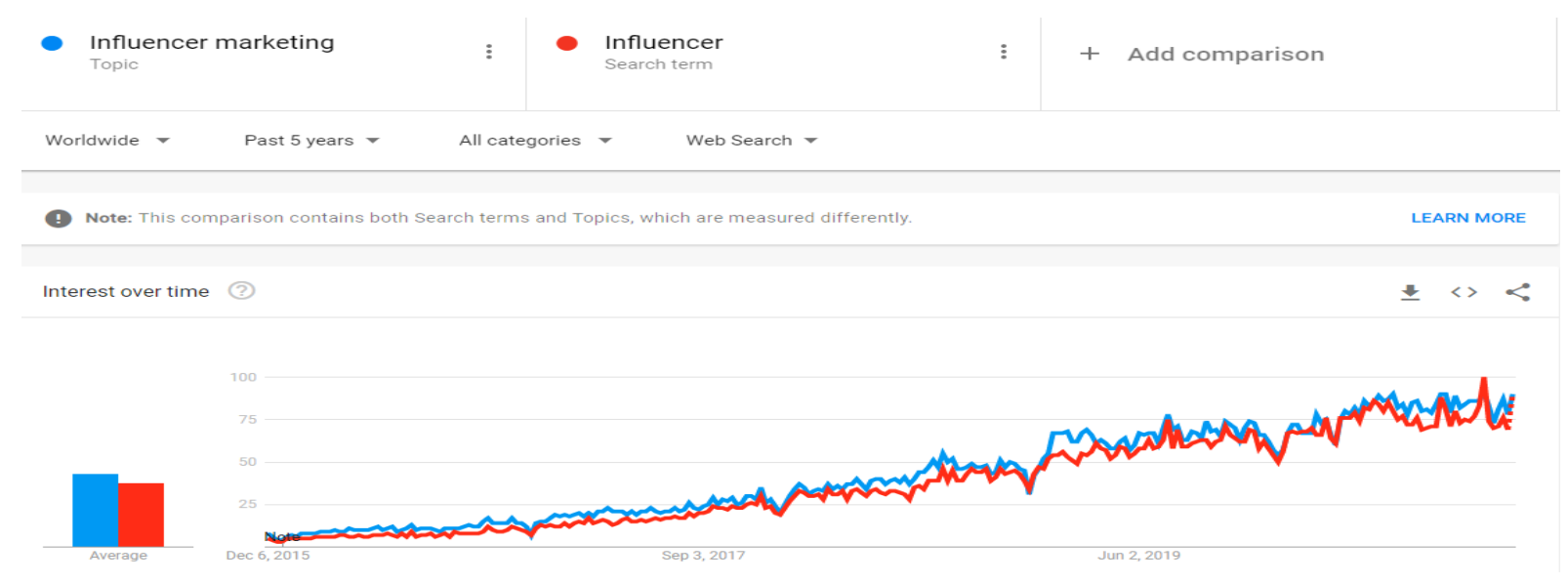

Figure 1. Google Trends

The use of technology, especially social media, has become an effective marketing communication channel for companies to maintain their values and brand identity. Effective communication is one of the keys to success in information services, ensuring that information services will be handled quickly as expected (Rahartri, 2019). This is a major driving force for Influencers who are able to increase their exposure quickly where these Influencers take advantage of their social media activities. Social media marketing can create loyal customers, increase traffic and good exposure for the web, affect SEO and search results on Google, and can increase sales (Defrianto \& Loisa, 2019). Previous research has discussed a lot about the influencer phenomenon on marketing activities, especially in the advertising field. The main focus of this research is how the influencer phenomenon can be useful for creative agencies and can be used as a business model for them.

\section{Creative Agency}

The role and contribution of the creative industry can no longer be underestimated, in 2019 the creative industry has contributed to Indonesia's GDP of around Rp. 1200 trillion (Bekraf, 2019). Creative Agency can be seen as a subsection focusing on, for example, art, design, entertainment, and advertising (Lampel, Lant \& Shamsie 2000). The role of the agency, especially the creative agency, has an important role in the development of marketing strategies where every effort to understand the process related to "how marketing occurs" must take into account the contribution of the marketing agency itself (Keegan J, Rowley J \& Tonge J, 2017). Agency creativity is an integral part of advertising creativity which refers to the creative quality of the team in it which aims to produce innovative advertisements (O'Conner, Willemain and MacLachlan; Smith and Yang 2004). Creative agencies as companies must also have a high reputation by having broad public trust and a strong commitment to resolve every consumer 


\section{Jurnal Manajemen dan Bisnis: Performa Vol. 18, No. 2 September 2021}

complaint in accordance with the Services Level Agreement (Permana RMT \& Pratama RARJ, 2020).

\section{Electronic Word of Mouth}

Hennig-Thurau et al. (2004) defined eWOM as "a positive or negative statement made by a potential, actual customer about a product or company, which is made available to many people and institutions through the Internet". Also note that eWOM may be less personal because it's not face-to-face but more powerful because it's direct, has significant reach, and is accessible to others. eWOM enables consumers to obtain information regarding goods and services from a few people they know and from a large group of geographically dispersed people who have experience with the relevant product or service. Effective WOM communication media is carried out face to face in the 40-44 year age range, through online media in the 35-39 year age range, while the community is used for the 15-24 year age range (Rohandi, 2016). Getting the most relevant and comprehensive information to customers will result in higher information adoption. (Jalilvand et al, 2010). For products with luxury brands, social media marketing efforts can be seen from five dimensions: entertainment, interaction, trends, customization, and word of mouth (WOM) (Kim and Ko, 2012)

\section{Social Media Marketing}

Social media has profoundly changed the way people interact and communicate and is able to offer marketers a greater ability to connect with target customers. Social Media is a form of marketing in which media technologies, channels, and software are used to create value for customers and satisfy their wants and needs. In addition, according to Gay, Charlesworth, \& Esen, (2007) Social media marketing has the same goals as overall marketing, but the main difference is that marketing is done online, and more specifically on social media platforms. This includes all types of web-based software and services that enable users to get together online and communicate, communicate, exchange, and take part in various forms of digital social interaction. Social media opens up opportunities for marketers as a broad tool that allows them to reach consumers directly (Lee, J.E., \& Watkins, B. (2016).

\section{Influencer Marketing}

Influencer Marketing is seen as one of the best strategies to bring in potential customers when using social media marketing by leveraging the mass owned by Influencers, an influencer can create a better brand and product image at a lower cost than using an endorser artist brand or public figure who has been among the top artists. They are considered spokespeople in efforts to support products and increase brand awareness and consumer engagement (Nordqvist, 2018). Influencers are "a series of third parties who have influence over the organization and potential customers" (Peck et al., 2013). Influencer marketing can also be considered as a form of product placement as it involves intentionally incorporating a brand message in media content (Vodák et al., 2019). With the increasingly massive use of social media, influencer marketing utilizing social media reflects the unique and relatively different and novelty of this marketing strategy (Belanche, D., Casaló, LV, Flavián, M., \& Ibáñez-Sánchez, S. 2021 ). If you look at the reputation of influencers, it seems as if it comes from content posted on all their social media and sometimes in collaboration with their followers (Hu, Min, Han, \& Liu, 2020). This seems to be a pattern for people who use social media to see influencers from the number of followers. It should also be seen that consumer fit when looking at influencers is also seen from follower 
behavior, this match can make followers imitate or accept influencer suggestions (Casalo et al., 2020).

\section{Research Methodology}

The method used in this study is a qualitative method supported by quantitative data. According to Creswell (2014) says that the purpose of this approach is to understand, explore group or individual phenomena. In this study, we will analyze the social relationships of individuals or groups because Influencer marketing can be an appropriate group reference.

This study uses secondary data using third-party data contained in books, white papers, journals, articles, and others as a source of iteration, while for primary data using direct questionnaires (direct surveys) or group administration methods using google forms distributed on e-mail and social applications. (WhatsApp, Line, Instagram, etc.). In the survey design, this research will measure the level of trust from respondents to influencer. In this study there are two kinds of variables, namely the variable creation (dependent variable) is a variable that depends on other variables and the independent variable (independent variable) is a variable that does not have a dependency on other variables. The variables that are the focus of this research are Influencer marketing as the independent variable in the new creative Agency business model as the dependent variable. Measurement of variables is done using a Likert scale, where data from each variable will use the form of numbers or quantitative data that is scored (scoring) ranging from strongly disagree with a score of 1 to 5 strongly agree.

In this study, the population is determined by all Indonesians who use social media such as Youtube, Facebook, Instagram, and Twitter with an unknown number. To get the sample, the researcher used Judgment sampling. the number of samples obtained using the Bernoulli method with an error of $5 \%$ so that the minimum number of respondents is 200 respondents from active social media users, be it students, employees, or housewives.

Data analysis will be carried out after collecting data which is then analyzed with the help of a statistical program (SPSS) using the t-test, F test, and U test. The t-test was used to test the hypothesis partially and F test was used to test the hypothesis simultaneously. And the last is to find the coefficient of determination to show the influences that are not included in this study.

\section{Results and Discussion}

From the results of a questionnaire that has been distributed to 200 respondents regarding the use of mass social media which currently greatly affects the role of influencers in the creative industry. In general, social media is used as a place for work and also promotion (endorse) through influencers. Influencer content refers to posts shared by influencers consisting of images, captions, and hashtags.

\section{Analysis of Respondents Characteristics}

Respondent analysis was carried out before the discussion in this study. Respondent analysis is a process of describing the results of the respondents' questionnaires that have been obtained in this study based on gender, age, occupation and use of social media. The purpose of respondent analysis is to determine the diversity of the various respondents that have been obtained by researchers. The number of samples used in this study amounted to 200 respondents the results of the calculation of the sample search using the Bernoulli method. The distribution 
of the respondent's characteristics serves as a way to determine the magnitude of the influencer's influence for the continuity of the creative agency business.

\section{Analysis Based on Respondent Age}

In this study, the age of the respondents was grouped into five groups, namely the age group of respondents under 18 years, the group 18-25 years, the group 26-35 years, the group 36-50 years, and the group above. 50 years. Based on the results of the study showing the age of the respondents, it was explained that the percentage for the 18-25 year group was $45.1 \%$, then for the 26-35 year group 43.6\%, the 36-50 year group. the group was $8.3 \%$, and the group over 50 years was $3 \%$. Based on these results, it can be seen that the age group with the largest percentage is in the 18-25 year age group of $45.1 \%$ and the 26-35 year age group of $43.6 \%$. This is because the majority of active users of social media are between the ages of 18 and 35, both for online shopping, communicating, and seeking information.

\section{Analysis Based on Active Social Media}

Shows the number of numbers who use social media by $90.2 \%$ using social media. In addition, the average person who uses social media can spend 2 hours to 5 hours a day accessing social media. With a large number of social media users, it can provide the benefits of social media, namely being able to use social media in conducting promotions to the target community. By promoting using social media, you can quickly spread the promotion, and the costs used will be cheaper than using traditional promotions, for example using brochures, and others.

Currently, there are many social media applications that are used by the public to access various things, such as WhatsApp, Facebook, Instagram, and others. However, from the results of the questionnaire, it was found that the order of the most popular social media obtained by the community is as shown in Figure 2 as follows:

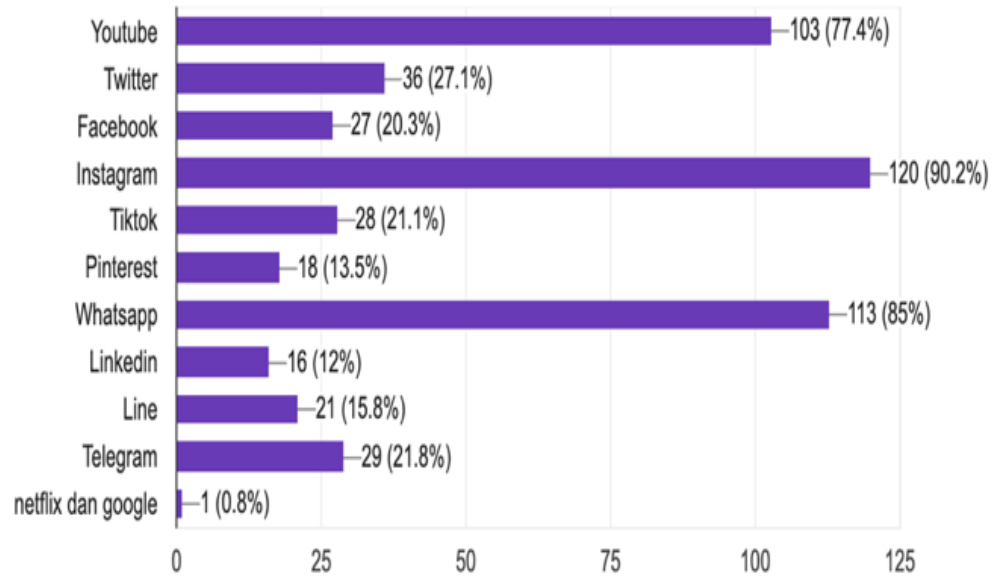

Figure 2. Most Popular Social Media

\section{Influencer Data Analysis}

In general, an influencer is someone who can make an impact on society. These influencers can be from artists, bloggers, YouTubers or people who have figures in certain communities. In accordance with the purpose of this study to analyze the impact of Influencer marketing and help identify changes in market behavior (market) that occur in the realm of Creative Agency to be able to formulate a new business model The results show that the 
responses of respondents who know influencers are $91.7 \%$ of respondents know the meaning of influencers and $7.5 \%$ do not know influencers. This is because companies are starting to use influencers to endorse someone in promoting brands, products, and reviews. But nowadays, many people see influencers in terms of the content they offer, such as trending lifestyles, food, fashion, music shows, make-up tutorials and so on. From $91.7 \%$ of respondents who know influencers also follow and mention some of the names of influencers they follow.

\section{T test Analysis}

In this study, the variables used are influencer as the dependent variable and creative agency as the independent variable. In the T-test to test the effect of each independent variable on the dependent variable, the following criteria are used:

- H0: Influencers have no effect on creative agencies

- H1: Influencers have an effect on creative agencies

Table 1. correlation of influencers to creative agencies Correlations

\begin{tabular}{|c|c|c|c|}
\hline & & Influencer & $\begin{array}{c}\text { AgencyCreati } \\
\text { ve }\end{array}$ \\
\hline \multirow[t]{3}{*}{ Influencer } & Pearson Correlation & 1 & $.878^{* *}$ \\
\hline & Sig. (2-tailed) & & .000 \\
\hline & $\mathrm{N}$ & 130 & 130 \\
\hline \multirow[t]{3}{*}{ AgencyCreative } & Pearson Correlation & $.878^{* *}$ & 1 \\
\hline & Sig. (2-tailed) & .000 & \\
\hline & $\mathrm{N}$ & 130 & 130 \\
\hline
\end{tabular}

Regarding the correlation of influencers to creative agencies, the results of the Pearson correlation are 0.878 for the influencer variables to creative agencies.

\section{F test Analysis}

In this study, we want to see whether the independent variable (influencer) simultaneously has a significant effect on the dependent variable or not. Therefore, to determine the level of significant influence of influencers on creative agencies, it is necessary to test the correlation coefficient or $\mathrm{F}$ test. Attached are the results of data processing using SPSS for statistical testing F test:

Tabel 2. Model Summary

\begin{tabular}{|c|c|c|c|c|c|c|c|c|c|c|}
\hline \multicolumn{11}{|c|}{ Model Summary ${ }^{b}$} \\
\hline \multirow[b]{2}{*}{ Model } & \multirow[b]{2}{*}{$R$} & \multirow[b]{2}{*}{ RSguare } & \multirow[b]{2}{*}{$\begin{array}{c}\text { Adjusted R } \\
\text { Square }\end{array}$} & \multirow[b]{2}{*}{$\begin{array}{l}\text { Stid. Error of } \\
\text { the Estimate }\end{array}$} & \multicolumn{5}{|c|}{ Change Statistics } & \multirow[b]{2}{*}{$\begin{array}{l}\text { Durbin- } \\
\text { Watson }\end{array}$} \\
\hline & & & & & $\begin{array}{l}\text { RS Square } \\
\text { Change }\end{array}$ & FChange & df1 & $d f 2$ & Sig. F Change & \\
\hline 1 & $.878^{\mathrm{d}}$ & .771 & .769 & 3.79678 & .771 & 429.761 & 1 & 128 & .000 & 1.807 \\
\hline \multicolumn{11}{|c|}{ a. Predictors: (Constant), INFLEENCER } \\
\hline \multicolumn{11}{|c|}{ b. Dependent Variable: ACENCYCREATIVE } \\
\hline
\end{tabular}

Sources : Data Processed on SPSS, 2021

The result of $\mathrm{R}$ square is 0.771 or $77.1 \%$. This means that $77.1 \%$ of the contribution of the independent variable to the dependent variable or it can be said that $77.1 \%$ of influencers are 
caused by creative agencies and the remaining $22.9 \%$ are other variable factors not examined in this study. In addition, the standard error of the estimate in the results of this study is 3.79678 or $3.8 \%$, meaning that the model is quite accurate in predicting the dependent variable.

Tabel 3. Result of $\mathbf{F}$ test

\begin{tabular}{|c|c|c|c|c|c|c|}
\hline \multicolumn{7}{|c|}{ ANOVA $^{\mathrm{a}}$} \\
\hline \multicolumn{2}{|c|}{ Model } & $\begin{array}{l}\text { Sum of } \\
\text { Squares }\end{array}$ & $d f$ & Mean Square & $F$ & Sig. \\
\hline \multirow[t]{3}{*}{1} & Regression & 6195.240 & 1 & 6195.240 & 429.761 & $.000^{b}$ \\
\hline & Residual & 1845.190 & 128 & 14.416 & & \\
\hline & Total & 8040.431 & 129 & & & \\
\hline \multicolumn{7}{|c|}{ a. Dependent Variable: ACENCYCREATIVE } \\
\hline \multicolumn{7}{|c|}{ b. Predictors: (Constant), INFLUENCER } \\
\hline
\end{tabular}

Sources : Data Processed on SPSS, 2021

From the results of processing the questionnaire data that has been obtained by the researchers in table 5.5, the results of the F-test value are 429,761 with a significant level of 0.000 . Because the probability value in this research test is 0.000 , the value is smaller than 0.05 , so it can be concluded that influencers have an effect on creative agency. It can be concluded that with the influence of influencers on creative agencies, influencers can become tools in the creative agency business model. In addition, previous research according to Defrianto (2019) stated that influencers have a role to help companies deliver marketing messages that can be accepted by all groups. So that the influencer role can be used in agency creatives.

\section{Conclusions}

From the results of this study, it can be concluded that influencers have a significant role in the business processes of creative agencies. This is shown from the respondents' results which show that $91.7 \%$ of respondents know the role and function of influencers. Where some of the influencers depicted from the survey results have quite significant followers and the variety of content they create. This is one of the factors for creative agencies to be able to take advantage of the role of influencers in developing their business models.

One of the factors that influencers are well known by respondents can be seen from the intense use of social media used by respondents, which is indicated by an average of 2 - 5 hours in one day. the tendency of social media users to view and consume brand-related content for pleasure, relaxation, and entertainment (Muntinga et al., 2011). This can be used as a tool for creative agencies in utilizing the right business model is facing competition in the creative industry today by utilizing the role of Influencers on social media.

The business model that will be proposed is a model from the perspective of consumer needs for content created by Influencers. The different model approaches can be done by looking at the role of influencers further by segmenting the content produced, where creative agencies can map out the right role in utilizing influencers in their business activities. The variety of business models to choose from can enhance agency creativity by generating more (and better) ideas through the sharing of knowledge, skills, and expertise (Lynch, J., \& West, D. C., 2017) 


\section{REFERENCES}

Badan Ekonomi Kreatif (Bekraf). 2019. Laporan Kinerja Badan Ekonomi Kreatif Tahun 2019. https://www.kemenparekraf.go.id/asset_admin/assets/uploads/media/pdf/media_15988797 01_BUKU_BEKRAF_28-8-2020.pdf.

Casalo, L. V., Flavían, C., \& Ib'ã nez-S' anchez, S. (2020). Influencers on Instagram: Antecedents and consequences of opinion leadership. Journal of Business Research, 117, 510-519. https://doi.org/10.1016/j.jbusres.2018.07.005

Charlesworth, A. (2014). Digital marketing: A practical approach. Routledge.

Contestabile, G. 2018. Influencer Marketing in 2018: Becoming an Efficient Marketplace. AdWeek.

Creswell, J. W. (2014). Research design: qualitative, quantitative, and mixed methods approaches. 4th ed. Thousand Oaks, California: SAGE Publications.

Defrianto, D., \& Loisa, R. (2019). Efektivitas Social Media Marketing E-Commerce dalam Meningkatkan Brand Image Perusahaan (Survei Pada Pelanggan Tokopedia). Prologia, 3(2), 505. https://doi.org/10.24912/pr.v3i2.6398.

Dhanesh, G. S., \& Duthler, G. (2019). Relationship management through social media influencers: Effects of followers' awareness of paid endorsement. Public Relations Review, 45(3), 101765. https://doi.org/10.1016/j.pubrev.2019.03.002

Hennig-Thurau, T., Gwinner, K. P., Walsh, G., \& Gremler, D. D. (2004). Electronic word-ofmouth via consumer-opinion platforms: What motivates consumers to articulate themselves on the Internet? Journal of Interactive Marketing, 18(1), 38-52. https://doi.org/10.1002/dir.10073.

Hu, L., Min, Q., Han, S., \& Liu, Z. (2020). Understanding followers' stickiness to digital influencers: The effect of psychological responses. International Journal of Information Management, 54, 102169. https://doi.org//10.1016/j.ijinfomgt.2020.102169

Jalilvand, M. R., Esfahani, S. S., \& Samiei, N. (2011). Electronic word-of-mouth: Challenges and opportunities. Procedia Computer Science, 3, 42-46. https://doi.org/10.1016/j.procs.2010.12.008.

Khamis, S., Ang, L., \& Welling, R. (2016). Self-branding, "micro-celebrity" and the rise of Social Media Influencers. Celebrity Studies, 8(2), 191-208. https://doi.org/10.1080/19392397.2016.1218292.

Keegan, Brendan \& Rowley, Jennifer \& Tonge, Jane. (2017). Marketing Agency-Client Relationships: Towards A Research Agenda. European Journal of Marketing. 51. https://doi.org/10.1108/EJM-10-2015-0712.

Kim, D. Y., \& Kim, H.-Y. (2021). Influencer advertising on social media: The multiple inference model on influencer-product congruence and sponsorship disclosure. Journal of Business Research, 130, 405-415. https://doi.org/10.1016/j.jbusres.2020.02.020 
Kim, A. J., \& Ko, E. (2012). Do social media marketing activities enhance customer equity? An empirical study of luxury fashion brand. Journal of Business Research, 65(10), 1480-1486. https://doi.org/10.1016/j.jbusres.2011.10.014.

Lampel, J., Lant, T., \& Shamsie, J. (2000). Balancing Act: Learning from Organizing Practices in Cultural Industries. Organization Science, 11(3), 263-269. https://doi.org/ 10.1287/orsc.11.3.263.12503.

Lee, J. E., \& Watkins, B. (2016). YouTube vloggers' influence on consumer luxury brand perceptions and intentions. Journal of Business Research, 69(12), 5753-5760. https://doi.org/10.1016/j.jbusres.2016.04.171

Lynch, J., \& West, D. C. (2017). Agency Creativity: Teams and Performance. Journal of Advertising Research, 57(1), 67-81. https://doi.org/10.2501/jar-2017-006

Muntinga, D. G., Moorman, M., \& Smit, E. G. (2011).Introducing COBRAs: Exploring motivations for brand-related social media use.International Journal of Advertising,30(1), 1346.5840B. Godey et al. / Journal of Business Research 69 (2016) 5833-5841.

Nordqvist, C. (2018). 3 Ways Influencer Marketing Contributes to Business Success. Retrieved from https://marketbusinessnews.com/influencer-marketing/190224/.

Peck, H., Christopher, M., Clark, M., \& Payne, A. (2013). Relationship Marketing. https://doi.org/10.4324/9780080525150

Permana, R. M. T., \& Pratama, R. A. R. J. (2020). Making Effectiveness Customer Complaint Handling. Almana: Jurnal Manajemen Dan Bisnis, 4(2), 237-243. https://doi.org/10.36555/almana.v4i2.1398.

Rahartri. 2019. "Whatsapp" Media Komunikasi Efektif Masa Kini (Studi Kasus Pada Layanan Jasa Informasi Ilmiah Di Kawasan Puspiptek). Perpustakaan Nasional. Visi Pustaka Vol. 21, No. 2, Agustus 2019.

Rohandi, MMA. 2016. Effective Marketing Communicaton : Word Of Mouth. Jurnal Manajemen dan Bisnis: Performa Vol.13, No. 1 Tahun 2016.

Smith, R. E., \& Yang, X. (2004). Toward a General Theory of Creativity in Advertising: Examining the Role of Divergence. Marketing Theory, 4(1-2), 31-58. https://doi.org/10.1177/1470593104044086

Todisco M. (2017). Why Influencer marketing is essential for any business looking to grow. Forbes. December.

Vodák, J., Novysedlák, M., Čakanová, L., \& Pekár, M. (2019). Influencer Marketing as a Modern Phenomenon in Reputation Management. Managing Global Transitions, 17(3). https://doi.org/10.26493/1854-6935.17.211-220 